\title{
Pengembangan Video Pembelajaran Matematika Berbantuan Sparkoll Videoscribe
}

\author{
Fiqi Nur Rohman*, Lenny Kurniati, Ratih Kusumawati \\ Universitas Ivet \\ *fiqinurrohman@gmail.com
}

\begin{abstract}
ABSTRAK
Video pembelajaran yang dibuat secara khusus dapat dijadikan media pembelajaran yang efektif. Video pembelajaran cenderung jelas dan lebih mudah dipahami karena didukung dengan aspek audio dan visual. Asumsi tersebut didukung dengan banyaknya software atau aplikasi yang bisa digunakan untuk membuat Video pembelajaran seperti Sparkoll Videoscribe. Sparkoll Videoscribe merupakan sebuah software yang menggabungkan beberapa rangkaian gambar menjadi sebuah video animasi. Sparkoll Videoscribe menyajikan konten pembelajaran dengan memadukan gambar, suara, dan desain yang menarik sehingga siswa mampu menikmati proses pembelajaran. Tujuan penelitian ini adalah mengembangkan video pembelajaran matematika berbantuan Sparkoll Videoscribe. Penelitian ini menggunakan metode penelitian dan pengembangan $(R \& D)$ dengan metode Borg \& Gall (1983) yang disederhanakan menjadi 6 tahapan yaitu: Research and Information Colecting, Planning, Develop Preliminary form a Product, Preliminary Field Testing, Main Product Revision, Main Field Testing. Hasil Uji lapangan kepada 28 Siswa SMP didapatkan skor dengan nilai 3,3179 dan berada pada kategori Sangat Baik dengan rentang penilaian antara 1,00 - 4,00. Dapat disimpulkan bahwa Video Pembelajaran Matematika Berbantuan Sparkoll Videoscribe ini valid dan dapat digunakan sebagai media video pembelajaran.

Kata kunci: pembelajaran matematika, video pembelajaran, sparkoll videoscribe.
\end{abstract}

\section{ABSTRACT}

Specially designed learning videos can make effective learning media. Learning videos tend to be clear and easier to understand because they are supported by audio and visual aspects. This assumption is supported by a multitude of software or applications that could be used to make learning videos like Sparkoll Videoscribe. Sparkoll Videoscribe was a software that incorporated several sets of images into an animated video. Sparkoll Videoscribe presents the content of learning by combining pictures, sounds, and designs that attract students to enjoy the learning process. The purpose of this study was to develop a mathematical learning video that was supported by Sparkoll Videoscribe. The study uses research and development methods (r\&d) by the borg \& gall (1983) simplified to 6 steps Research and Information Collecting, Planning, Develop Preliminary form a Product, Preliminary Field Testing, Main Product Revision, Main Field Testing. Field test results for 28 junior high school students got a score of 3.3179 and fell into an excellent category with an assessment range between 1.00 and 4.00. It could be concluded that a mathematical learning video asissted by Sparkoll Videoscribe was valid and could be used as a learning video.

Keyword: mathematical learning, video learning, sparkoll videoscribe. 


\section{PENDAHULUAN}

Pandemi Covid-19 telah mempengaruhi semua sistem pendidikan dari tingkat prasekolah, sekolah dasar, sekolah menengah hingga lembaga perguruan tinggi. Berdasarkan laporan $A B C$ News 7 Maret 2020, penutupan sekolah dan perguruan tinggi terjadi di lebih dari puluhan negara karena pandemi Covid-19 (Purwanto et al., 2020). UNESCO memperkirakan bahwa hampir 900 juta pelajar telah dipengaruhi oleh penutupan lembaga pendidikan akibat pandemi Covid-19 (Nicola et al., 2020).

Akibat situasi pandemi Covid-19, pemerintah Indonesia menerapkan physical distancing bagi warga negara. Physical distancing yang harus diterapkan menyebabkan proses pembelajaran peserta didik dalam kelas harus diubah metodenya dengan learning from home atau belajar dari rumah (Herliandy et al., 2020).

Pembelajaran secara daring harus dikemas semenarik mungkin, penggunaan media pembelajaran dapat membantu dalam pembelajaran daring dan video pembelajaran merupakan salah satu media pembelajaran yang dapat membantu dalam pembelajaran daring. Banyak aplikasi yang bisa digunakan dalam pembuatan video pembelajaran contohnya seperti sparkoll videsocribe.

Sparkoll Videoscribe mampu menyajikan konten pembelajaran dengan memadukan gambar, suara, dan desain yang menarik sehingga siswa mampu menikmati proses pembelajaran. Fitur yang disediakan Software ini sangat beragam sehingga mampu menjadi media pembelajaran yang dapat disesuaikan dengan mata pelajaran yang diinginkan. Selain menggunakan desain yang telah disediakan di software ini, pengguna membuat desain animasi, grafis, maupun gambar yang sesuai dengan kebutuhan. Selain itu, pengguna juga dapat melakukan dubbing dan memasukkan suara sesuai kebutuhan untuk membuat video. Pembuatan Videoscribe juga dapat dilakukan secara offline sehingga tidak tergantung pada layanan internet, hal ini pastinya akan lebih memudahkan guru dalam membuat media pembelajaran menggunakan Sparkoll Videoscribe terutama dalam pembelajaran matematika.

Matematika merupakan ilmu yang mendunia atau menyeluruh sehingga ilmu pendidikan mengalami perkembangan. Matematika merupakan ilmu universal yang didasari dengan perkembangan teknologi modern, serta memiliki peran penting dalam berbagai disiplin dan dapat memajukan daya pikir manusia (Basuki, 2019). Dalam ilmu pendidikan salah satu mata pelajaran memiliki peran penting untuk mengembangkan potensi yang dimiliki siswa yaitu mata pelajaran matematika. Matematika merupakan pelajaran yang membutuhkan penalaran dan logika yang tinggi sehingga dalam memahami dan menerapkan konsep yang dipelajari siswa dituntut untuk cerdas, kreatif, terampil, dan mandiri pada kegiatan pembelajaran (Nurfitriyani, 2016). Berdasarkan hasil wawancara dengan beberapa siswa SMP yang mengatakan bahwa mereka sedikit kesulitan untuk memahami pembelajaran matematika khususnya pada materi bangun ruang karena contoh yang terdapat dibuku masih berupa gambar 2 dimensi.

Bangun ruang adalah bangun yang memiliki ruang yang dibatasi oleh sisi-sisinya. Bangun ruang disebut juga bangun tiga dimensi. Adapun macam-macam bangun ruang yaitu kubus, balok, prisma, limas, tabung, kerucut, dan bola. Jenis bangun ruang juga terbagi menjadi dua yaitu, bangun ruang sisi lurus dan bangun ruang sisi lengkung. Yang termasuk ke dalam jenis bangun ruang sisi lengkung adalah tabung, kerucut, dan bola. Penyajian materi bangun ruang 
ke dalam bentuk video dirasa bisa digunakan sebagai alternatif untuk pembelajaran. Asumsi tersebut didukung dengan penelitian dari Rosiyanti et al., (2020) yang menyimpulkan bahwa penggunaan video pembelajaran dalam materi bangun ruang dapat meningkatkan penguasaan secara mandiri dan motivasi belajar.

Hasil penelitian (Indriyani \& Ganda Putra, 2018) menghasilkan media pembelajaran yang berbasis sparkol sangat layak dan sangat menarik untuk digunakan. Penelitian yang dilakukan memiliki kesamaan dengan penelitian-penelitian terdahulu yakni menghasilkan media pembelajaran berbasis Sparkol Videoscribe yang valid, layak, dan menarik untuk digunakan (Musyadat, 2015; Purnama et al., 2016; Wahyuni \& Sulistiyo, 2017; Wulandari, 2016).

Tujuan penelitian ini adalah untuk mengetahui bagaimana proses pengembangan video pembelajaran matematika berbantuan Sparkoll Videoscribe. Batasan dalam penelitian ini meliputi: (1) pengembangan yang dimaksud adalah pembuatan video pembelajaran matematika, (2) aplikasi yang digunakan dalam penelitian ini adalah Sparkoll Videoscribe, (3) fokus pengembangan lebih mengutamakan pembuatan video yang menarik bagi siswa, dan (4) materi yang disajikan pada video pembelajaran ini adalah bangun ruang sisi lengkung.

\section{METODOLOGI PENELITIAN}

Pengembangan Video Pembelajaran berbantuan Sparkoll Videoscribe ini menggunakan metode penelitian dan pengembangan (research and development) dengan pendekatan kualitatif. Penelitian dan pengembangan merupakan metode penelitian dengan tujuan untuk menghasilkan produk tertentu, dan menguji kelayakan produk tersebut. Penelitian dan pengembangan memiliki tujuan untuk menghasilkan produk baru melalui proses pengembangan (Sugiyono, 2013). Metode penelitian pengembangan yang digunakan adalah metode Borg \& Gall, (1983) yang dipersingkat menjadi 6 tahapan yaitu: (1) Research and Information Collecting, (2) Planning, (3) Develop Preliminary form a product, (4) Preliminary field testing, (5) Main Product Revision, (6) Main Field testing. Subyek penelitian ini adalah 28 siswa MTs NU 17 Kyai Jogoreso.

Teknik pengumpulan data yang digunakan adalah observasi, wawancara, lembar validasi ahli, dan angket respon siswa. Data dari lembar validasi ahli media dan materi akan diperoleh kritik dan saran perbaikan terhadap Video pembelajaran. Selain itu, akan diperoleh pula penilaian untuk menentukan kevalidan video pembelajaran. Angket yang diberikan kepada ahli media dan ahli materi kemudian dinilai dengan cara para ahli mengisi lembar angket validasi yang berisi butir-butir pernyataan yang dinilai menggunakan skala guttman. Skala guttman digunakan untuk mendapatkan jawaban yang jelas (tegas) dan konsisten terhadap permasalahan yang ditanyakan (Eko Putro, 2013).

Tabel 1. Kriteria Validasi Produk

\begin{tabular}{cc}
\hline Rentang Kategori Skor & Penafsiran \\
\hline $\mathrm{S} \min \leq \mathrm{V} \leq \mathrm{S} \min +(\mathrm{P}-1)$ & Tidak Layak \\
$\mathrm{S} \min +\mathrm{P} \leq \mathrm{V} \leq \mathrm{S} \max$ & Layak \\
\hline
\end{tabular}


Kepraktisan produk dapat diketahui melalui lembar angket respon siswa. Data dari lembar angket respon siswa dimaksudkan untuk mengetahui bahwa produk tersebut dapat dinyatakan praktis atau tidaknya. Selain itu, akan diperoleh pula penilaian untuk menentukan kevalidan video pembelajaran. Menurut Muhidin dalam Muhidin \& Abdurrahman, (2011) bahwa untuk mempermudah dalam mendeskripsikan variabel penelitian digunakan kriteria tertentu yang mengacu pada rata-rata skor kategori angket yang diperoleh responden. Penggunaan skor kategori ini digunakan sesuai dengan empat kategori skor yang dikembangkan dalam skala Likert dan digunakan dalam penelitian.

Tabel 2. Kriteria Kepraktisan Produk

\begin{tabular}{cc}
\hline Rentang Kategori Skor & Penafsiran \\
\hline $1,00 \leq \mathrm{V} \leq 1,75$ & Sangat Tidak baik / Sangat Rendah \\
$1,75 \leq \mathrm{V} \leq 2,50$ & Tidak Baik / Rendah \\
$2,50 \leq \mathrm{V} \leq 3,25$ & Baik / Tinggi \\
$3,25 \leq \mathrm{V} \leq 4,00$ & Sangat Baik / Sangat Tinggi \\
\hline
\end{tabular}

\section{HASIL DAN PEMBAHASAN}

Penelitian ini mengahsilkan produk berupa video pembelajaran menggunakan aplikasi Sparkoll Videoscribe. Penelitian ini dilaksanakan sesuai dengan metode penelitian pengembangan Borg \& Gall yaitu (1) Research and Information Collecting, (2) Planning, (3) Develop Preliminary form a product, (4) Preliminary field testing, (5) Main Product Revision, (6) Main Field Testing.

\subsection{Research and Information Collecting}

Analisis yang dilakukan dalam penelitian ini dilakukan melalui 2 kegiatan yaitu mengkaji materi dan studi literatur. Kompetensi dasar yang digunakan pada penelitian ini adalah Membuat generalisasi luas permukaan dan volume berbagai bangun ruang sisi lengkung (tabung, kerucut, dan bola), serta Menyelesaikan masalah konstektual yang berkaitan dengan luas permukaan dan volume bangun ruang sisi lengkung (tabung, kerucut, bola).

Salah satu penelitian yang digunakan penulis adalah penelitian Ramadhaniati et al., (2021). Penelitian yang berjudul "Pengembangan Video Pembelajaran Berbasis Sparkol (Videoscribe) Materi Limit Fungsi Untuk Siswa SMA Kelas XI”. Dalam penelitian ini peneliti menyimpulkan produk video pembelajaran berbasis Sparkol (Videoscribe) telah dinyatakan valid. Hal ini sesuai dengan pendapat Kustandi, (2013) Video merupakan media yang bisa memberikan suatu informasi atau berita, mengajarkan keterampilan, serta menjelaskan konsepkonsep yang sulit dimengerti, serta memaparkan proses mempersingkat atau memperlambat waktu dan mempengaruhi sikap. Sedangkan Sadiman, (2014) berkata bahwa video ialah gabungan dari media audio dan media visual yang dapat memunculkan gambar beserta suara di waktu yang sama. Sebuah pesan yang akan dihasilkan nantinya dapat berupa peristiwa penting, kejadian serta berita (fakta) maupun bersifat fiktif seperti contohnya sebuah cerita yang sifatnya edukatif dan informatif.

Pengumpulan informasi dilakukan dengan cara observasi dan wawancara. Observasi dilakukan pada saat pelaksanaan mata pelajaran matematika sedang berlangsung. Sedangkan wawancara dilakukan kepada guru mata pelajaran matematika di salah satu SMP tepatnya di 
MTS NU 17 Kyai Jogoreso Kendal. Dari hasil observasi dan wawancara didapatkan kesimpulan bahwa keterbatasan media dan kurangnya inovasi baru dalam pembelajaran menyebabkan kurang optimalnya proses pembelajaran, sehingga perlu dikembangkan media pembelajaran berupa media video pada mata pelajaran matematika.

\subsection{Planning}

Perencanaan yang dilakukan dalam pengembangan ini merumuskan kecakapan dan keahlian yang berkaitan dengan permasalahan, menentukan tujuan yang akan dicapai pada setiap tahapan dan jika mungkin atau diperlukan melaksanakan studi kelayakan secara terbatas. Memikirkan produk apa yang dihasilkan. Perencanaan dalam penelitian ini dilakukan melalui 4 tahap.

Tujuan dari penelitian ini adalah untuk mengembangkan suatu media pembelajaran berbentuk video pembelajaran dengan menggunakan aplikasi Sparkoll Videoscribe. Sparkoll Videoscribe dipilih karena mudahnya penggunaan aplikasi tersebut dan banyaknya pilihan animasi yang tersedia dalam aplikasi Sparkoll Videoscribe ini.

Hasil akhir dari produk yang dikembangkan adalah sebuah video pembelajaran dengan spesifikasi yang dapat dilihat pada Gambar 1. Dalam penelitian ini peneliti menggunakan bantuan beberapa instrument non-tes seperti: (1) angket respon ahli media, (2) angket respon ahli materi, (3) angket respon siswa, dan (4) video pembelajaran.

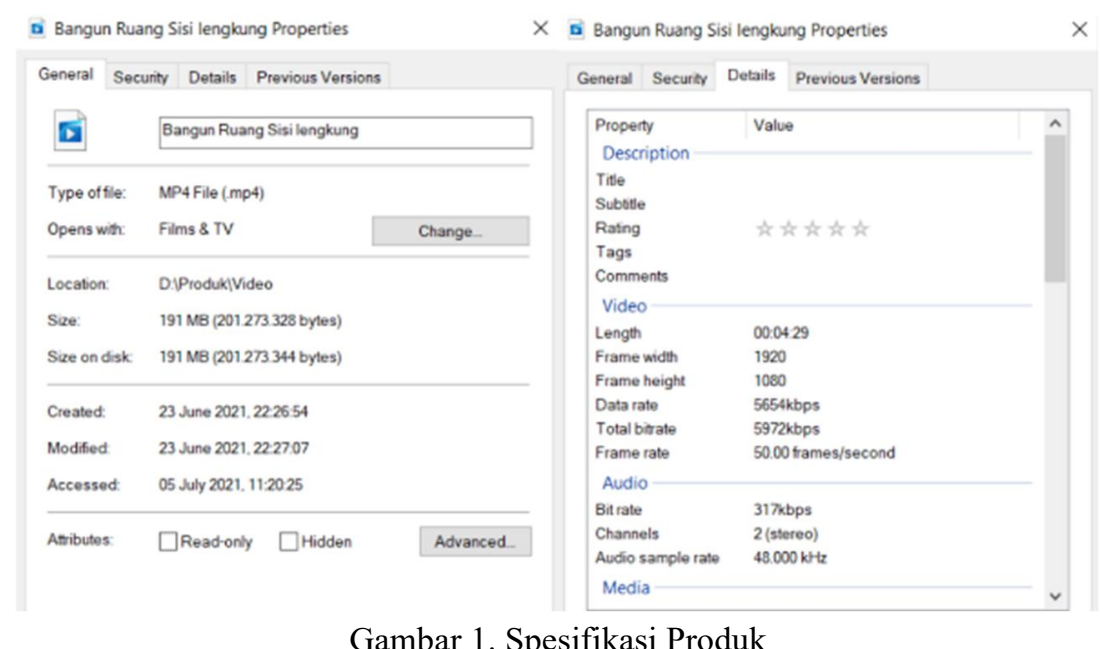

Gambar 1. Spesifikasi Produk

\subsection{Develop Preliminary Form a Product}

Proses dalam mengembangkan produk ini melalui tiga tahapan yaitu: tahap pra produksi, tahap produksi, tahap pasca produksi. Berikut ini merupakan hasil dari masing-masing tahapan.

\section{Pra Produksi}

Tahap produksi diawali dengan membuat identifikasi program yaitu dengan membuat Garis Besar Program Media (GBPM). Garis Besar Program Media (GBPM) yaitu identifikasi program yang meliputi mata pelajaran, sub materi, kompetensi inti, standar kompetensi, jenis media, dan judul media. Kemudian dilanjutkan dengan membuat sinopsis yang merupakan ringkasan cerita yang disampaikan secara singkat, padat, dan jelas tentang tema dari materi yang akan diproduksi. Dalam penulisannya, kalimat tidak diuraikan dengan kalimat panjang 
melainkan hanya dikemas dengan kalimat sederhana dan mencakup tema dan alur video tersebut. Setelah itu, langkah selanjutnya adalah membuat storyboard. Dalam pengembangan media video ini, storyboard yang dibuat merupakan gambaran umum berupa animasi dan narasi suara yang akan di rekam. Storyboard dibuat dalam 2 tahap, tahap pertama merupakan tahap penyusunan animasi yang akan digunakan dalam video pembelajaran. Tahap kedua merupakan tahap perekaman audio yang akan digunakan untuk narasi video.

\begin{tabular}{|c|c|}
\hline Aspek & Uraian \\
\hline Nama Mata pclaiarna & Masspatika \\
\hline Sub Materi & Bapgun ruans sisi lcagkung \\
\hline Kompeteosi Inti & 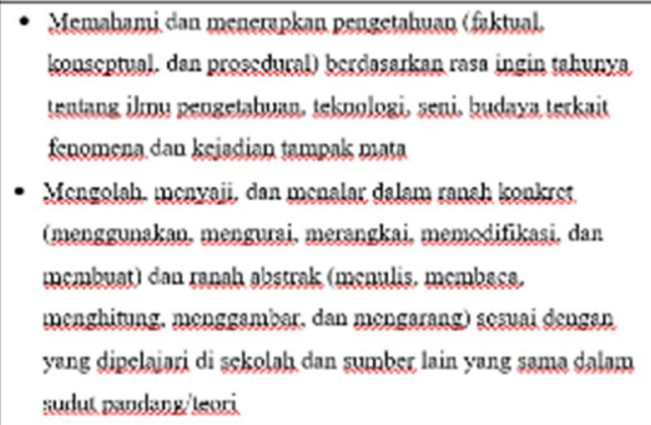 \\
\hline Kompetensi Dasar & 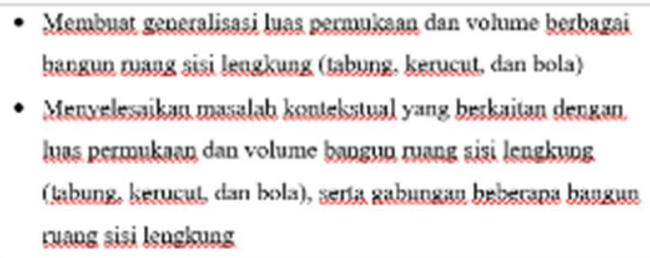 \\
\hline Jenis Media & Video Probbelaiaran \\
\hline Ludul & Video l'scubeliaiara Malsonslika \\
\hline
\end{tabular}

Gambar 2. GBMP Video Pembelajaran Matematika

\begin{tabular}{|c|c|c|}
\hline \multirow{2}{*}{ No } & \multicolumn{2}{|c|}{ Sinopsis } \\
\hline & Video & Audio \\
\hline 1 & Intro Video & $\begin{array}{l}\text { Adobe Premiere Pro Sound } \\
\text { Effect }\end{array}$ \\
\hline 2 & Animasi Salam Pembuka & $\begin{array}{l}\text { Narasi pembuka dan Salam } \\
\text { pembuka }\end{array}$ \\
\hline 3 & Judul Materi & Narasi materi \\
\hline 4 & $\begin{array}{l}\text { Penjelasan Bangun Ruang Sisi } \\
\text { lengkung }\end{array}$ & $\begin{array}{l}\text { Narasi singkat bangum ruang } \\
\text { sisi lengkung }\end{array}$ \\
\hline 5 & Menuju materi selanjutnva & Narasi materi tabung. \\
\hline 6 & Tabung. & $\begin{array}{l}\text { Narasi penielasan bangun } \\
\text { wang Tabung. }\end{array}$ \\
\hline 7 & Menuju materi selanjutnya & Narasi materi Kerucut \\
\hline 8 & Kerucut & $\begin{array}{l}\text { Narasi penjelasan bangun } \\
\text { wang Kencut }\end{array}$ \\
\hline 9 & Menuju materi selanjutnya & Narasi materi bola \\
\hline 10 & Bola & $\begin{array}{l}\text { Narasi pepielasan bangup } \\
\text { ruang Bola }\end{array}$ \\
\hline 11 & Pertanyaan Luas dan Volume & Narasi materi selanjutuxa \\
\hline
\end{tabular}

\begin{tabular}{|c|c|c|}
\hline \multirow{2}{*}{ No } & \multicolumn{2}{|c|}{ Sinopsis } \\
\hline & Video & Audio \\
\hline 12 & $\begin{array}{l}\text { Penjelasan singkat Luas dan } \\
\text { Volume }\end{array}$ & Narasi Luas dan Volume \\
\hline 13 & Menuiu materi selanjutnya & $\begin{array}{l}\text { Narasi Luas dan Volume } \\
\text { Tabung }\end{array}$ \\
\hline 14 & Luas dan Volume Tabung & $\begin{array}{l}\text { Narasi penjelasan Luas dan } \\
\text { Volume Tabung }\end{array}$ \\
\hline 15 & Menuiu materi selaniutnya & $\begin{array}{l}\text { Narasi Luas dan Volume } \\
\text { Kerucut }\end{array}$ \\
\hline 16 & Luas dan Volume Kerucut & $\begin{array}{l}\text { Narasi pepjelasan Luas dan } \\
\text { Volume Kerucut }\end{array}$ \\
\hline 17 & Menuju Materi selanjutuxa & Narasi Luas dan Volume Bola \\
\hline 18 & Luas dan Volume Bola & $\begin{array}{l}\text { Narasi penjelasan Luas dan } \\
\text { Volume Bola }\end{array}$ \\
\hline 19 & Conteb seal & $\begin{array}{l}\text { Narasi pemberian contob soal } \\
\text { dan mepuiu ke Latihan soal }\end{array}$ \\
\hline 20 & Latihan soal & Narasi pemberian Latihan soal \\
\hline 21 & Tampilan Keseluruban animasi & Narasi Penutup \\
\hline
\end{tabular}

Gambar 3. Sinopsis Video Pembelajaran Matematika 


\section{Produksi}

Kegiatan produksi pada pengembangan media video ini berisi pembuatan animasi dan rekaman suara (recording audio) sesuai dengan isi sinopsis yang telah dibuat sebelumnya. Sebelum tahap produksi dimulai perlu adanya persiapan alat untuk pembuatan video pembelajaran berupa Laptop yang akan digunakan untuk membuat animasi, record audio, dan proses editing. Peneliti sendiri menggunakan Laptop Acer Aspire 5 dengan spesifikasi:

$\begin{array}{ll}\text { Processor } & : \text { Intel Core } i \sim 3 @ 1,2(4 \text { CPUs) } \\ \text { RAM } & : 8 \mathrm{~Gb} \\ V G A & : \text { NVIDIA GeForce MX350 }\end{array}$

Setelah persiapan selesai, langkah selanjutnya adalah pembuatan animasi menggunakan aplikasi Sparkoll Videoscribe. Teknik pembuatan animasi sendiri menggunakan drawing animation yang mana nantinya animasi yang akan ditampilkan berupa sebuah gambar yang dilukis. Gambar-gambar yang akan digunakan untuk animasi sendiri dibuat menggunakan aplikasi Adobe Photoshop CS6 (64 bit).

Langkah selanjutnya adalah record audio. Dalam prosesnya peneliti menggunakan aplikasi Audacity untuk record dan editing audio yang akan digunakan untuk pengisi suara dalam animasi. Format audio yang akan digunakan adalah Mp3 dengan Bit rate 320 Kbps. Hasil audionya nanti akan menjadi narator dalam animasi Video Pembelajaran Matematika. Adapun proses dan hasil dari animasi ini dapat dilihat pada Gambar 4-13.

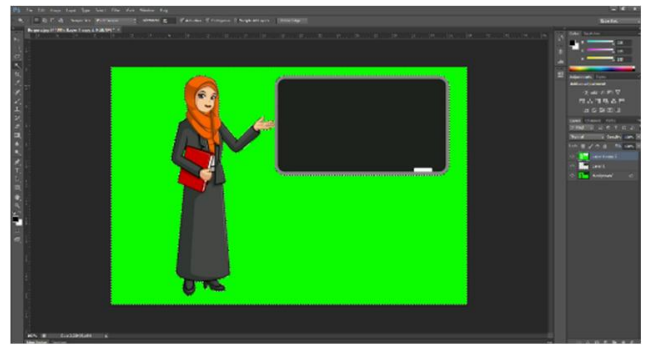

Gambar 4. Proses Pembuatan Gambar Animasi

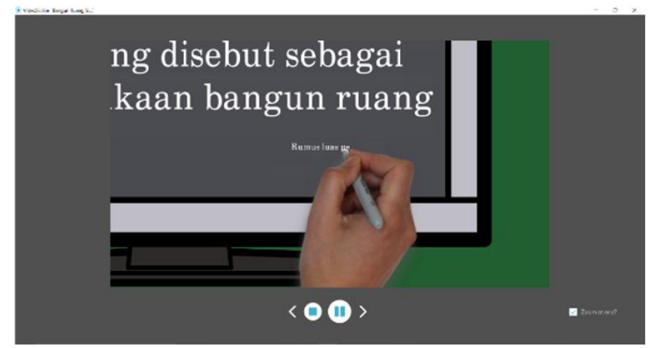

Gambar 5. Proses Pembuatan Animasi

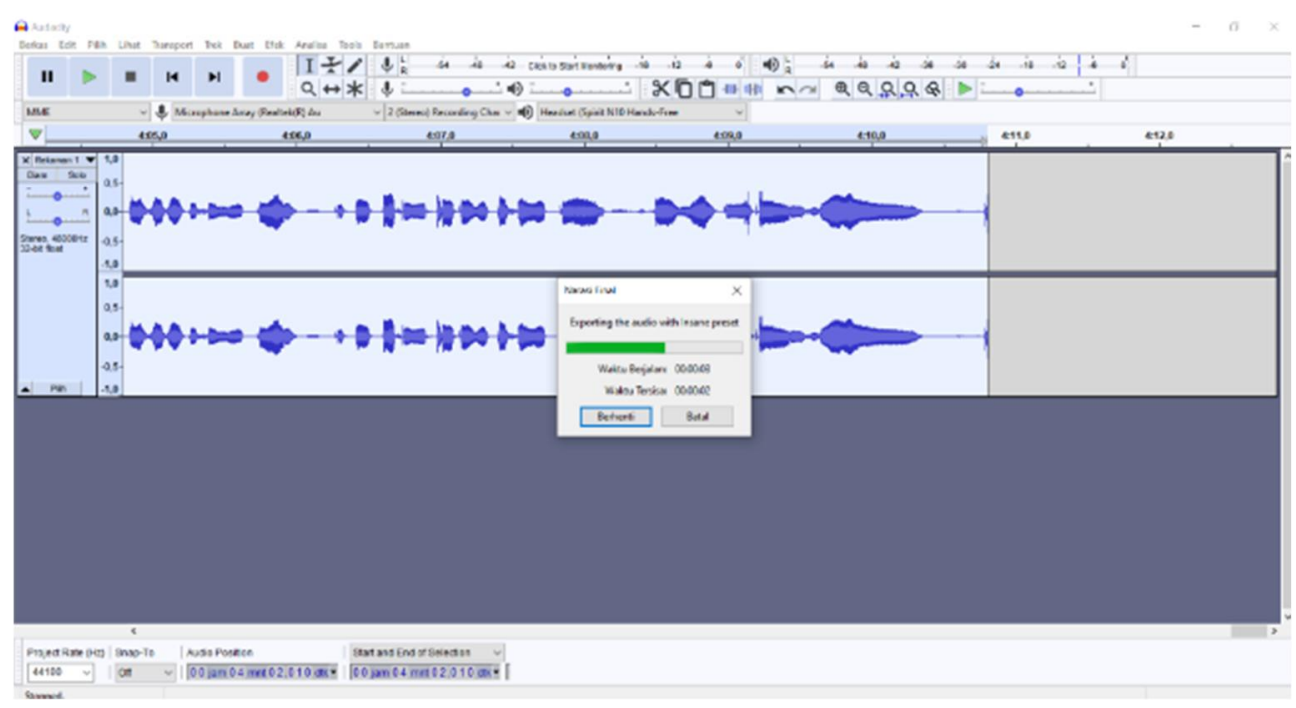

Gambar 6. Record dan Mixing Audio 


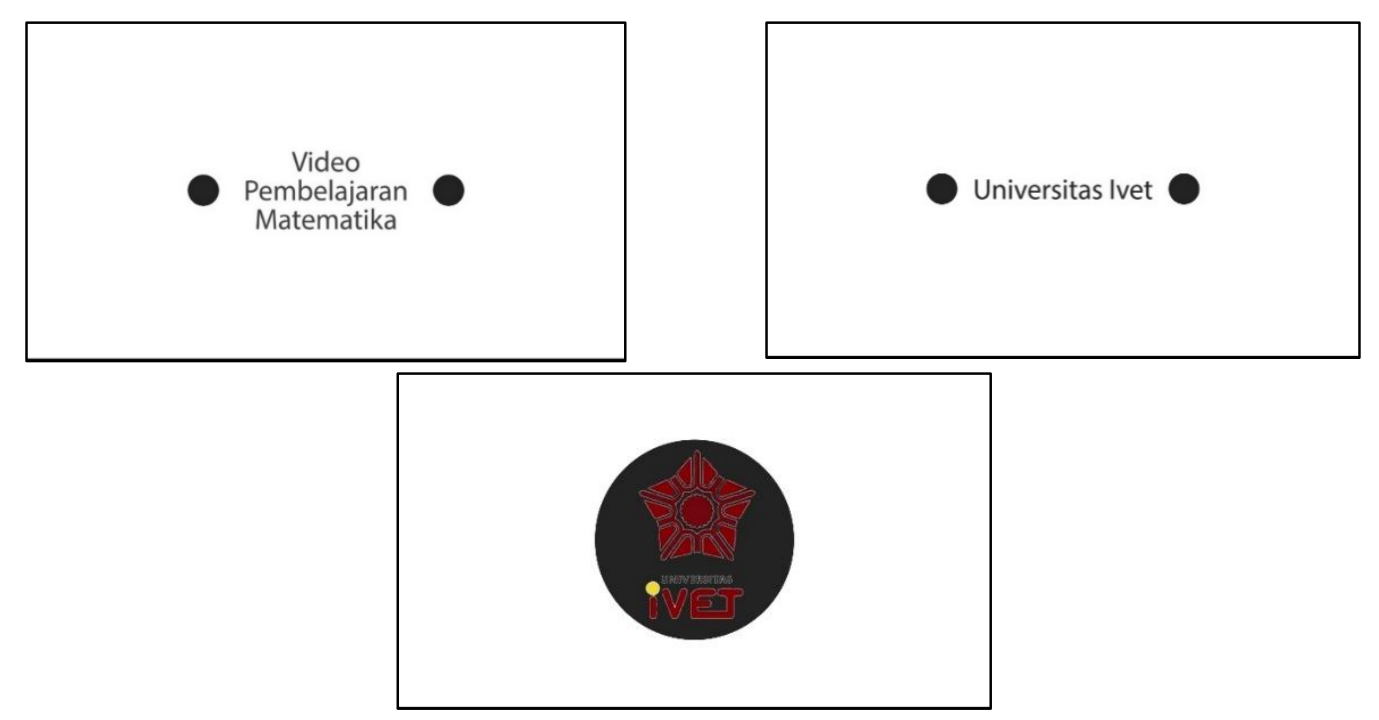

Gambar 7. Video Pembuka
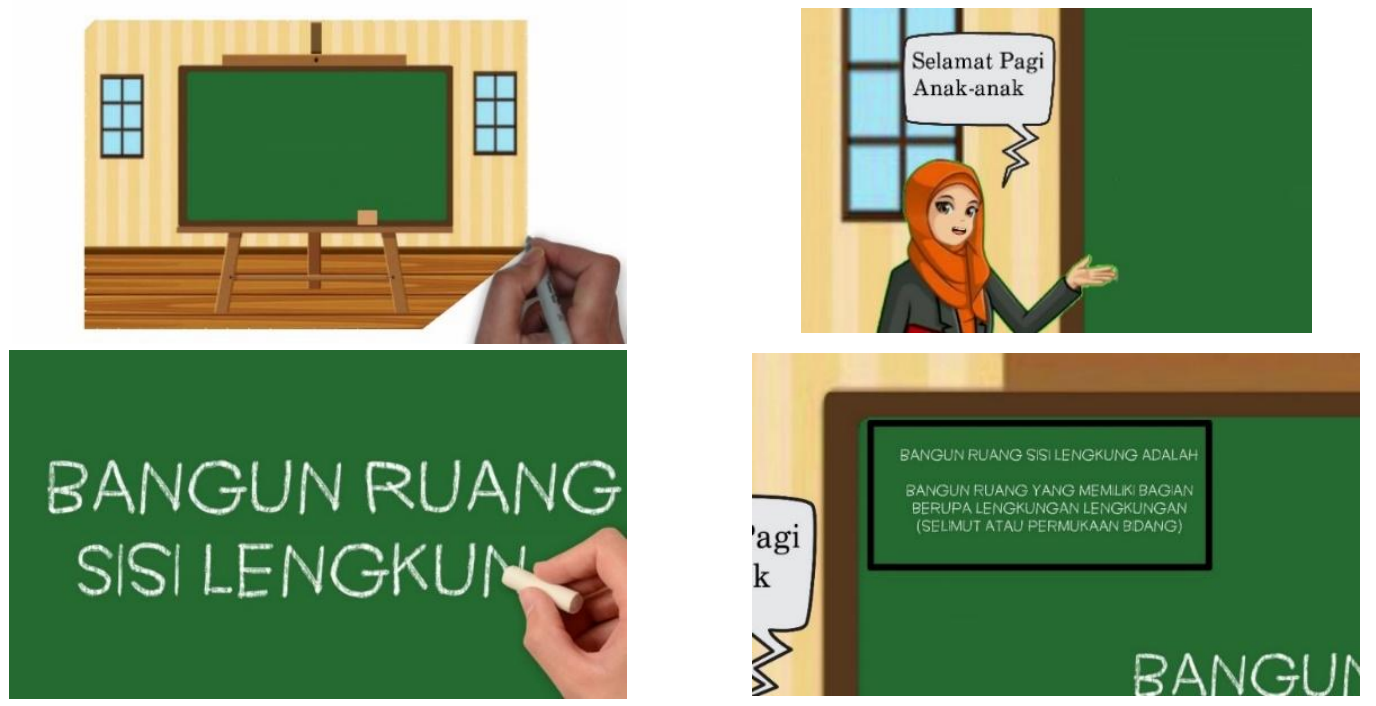

Gambar 8. Pengantar Materi
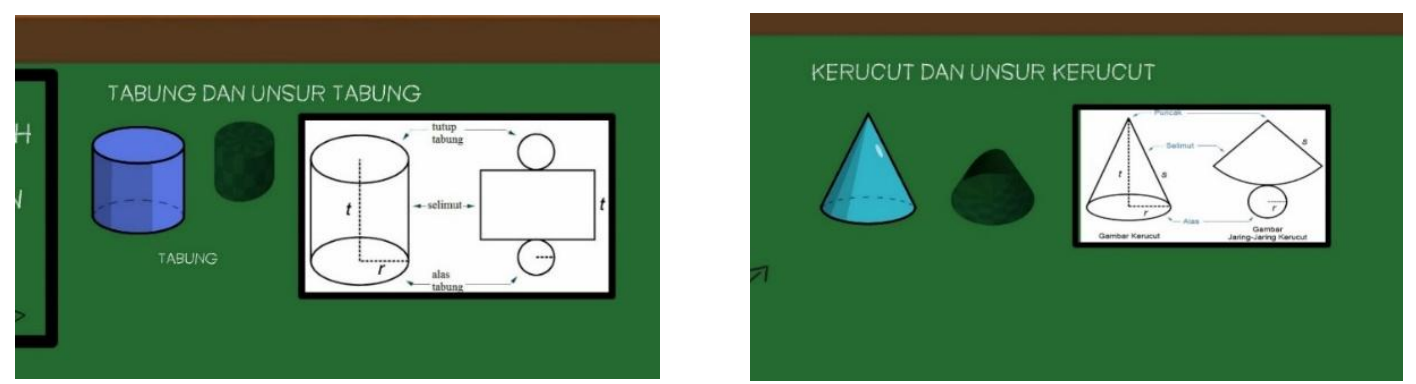

BOLA DAN UNSUR BOLA
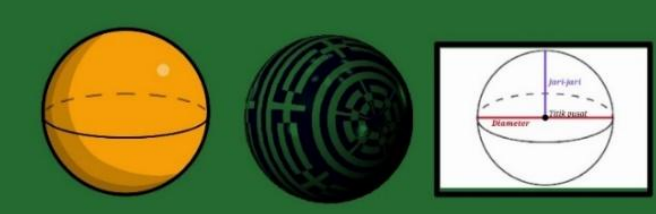

Gambar 9. Materi Inti 

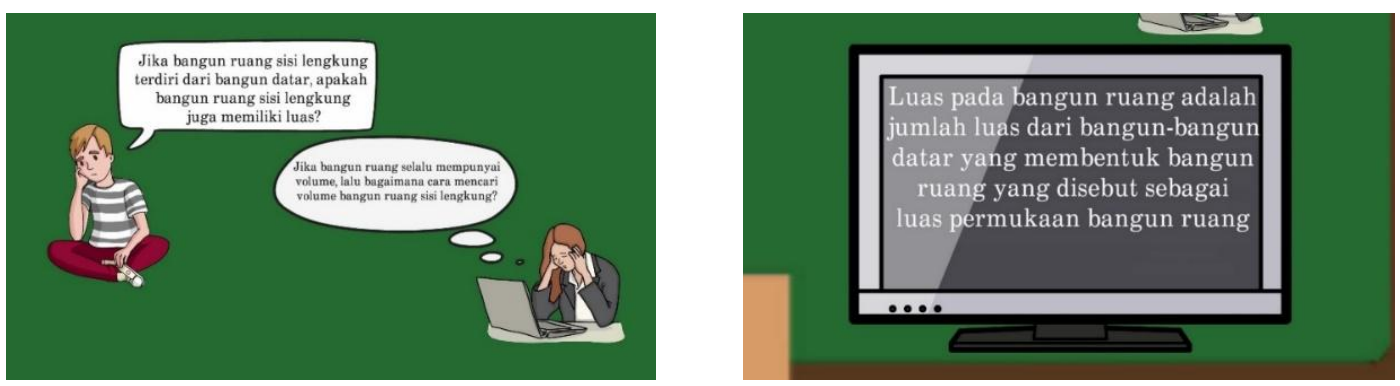

Gambar 10. Penegasan Materi
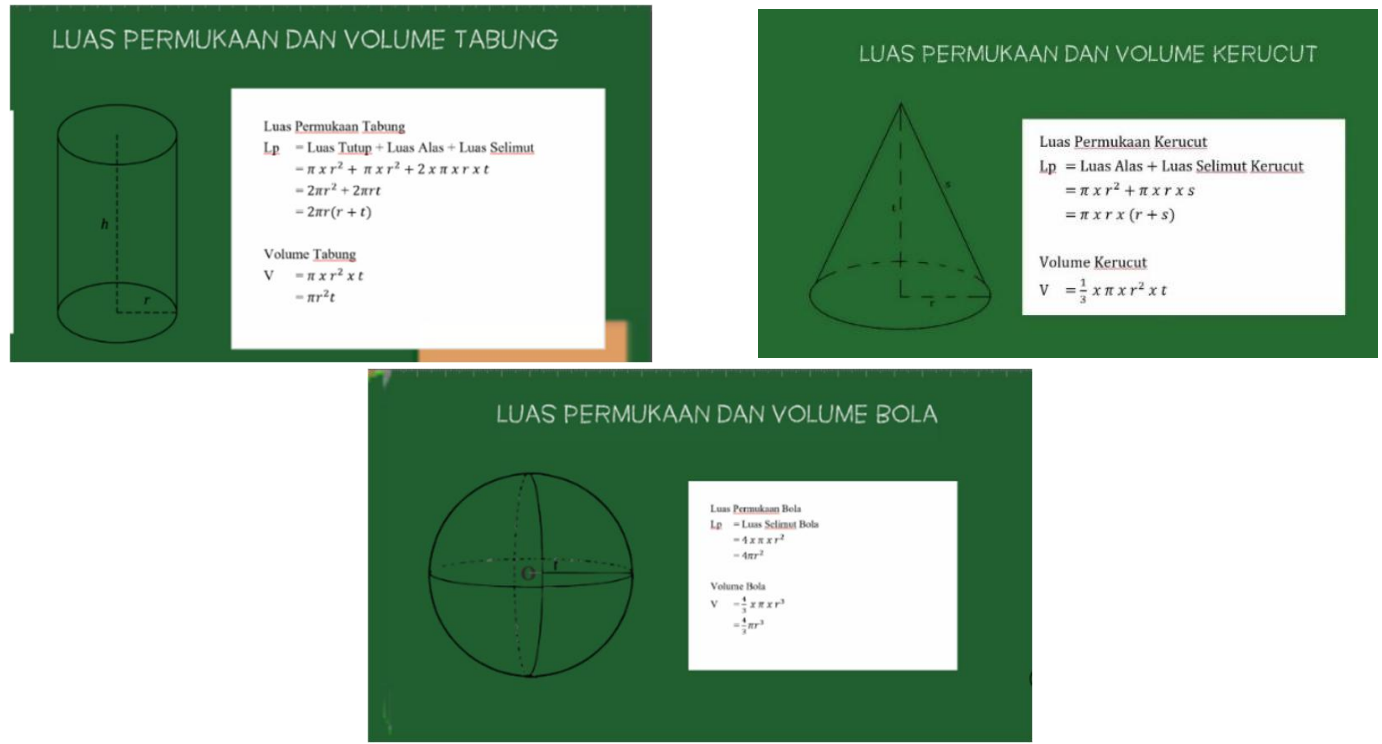

Gambar 11. Rumus
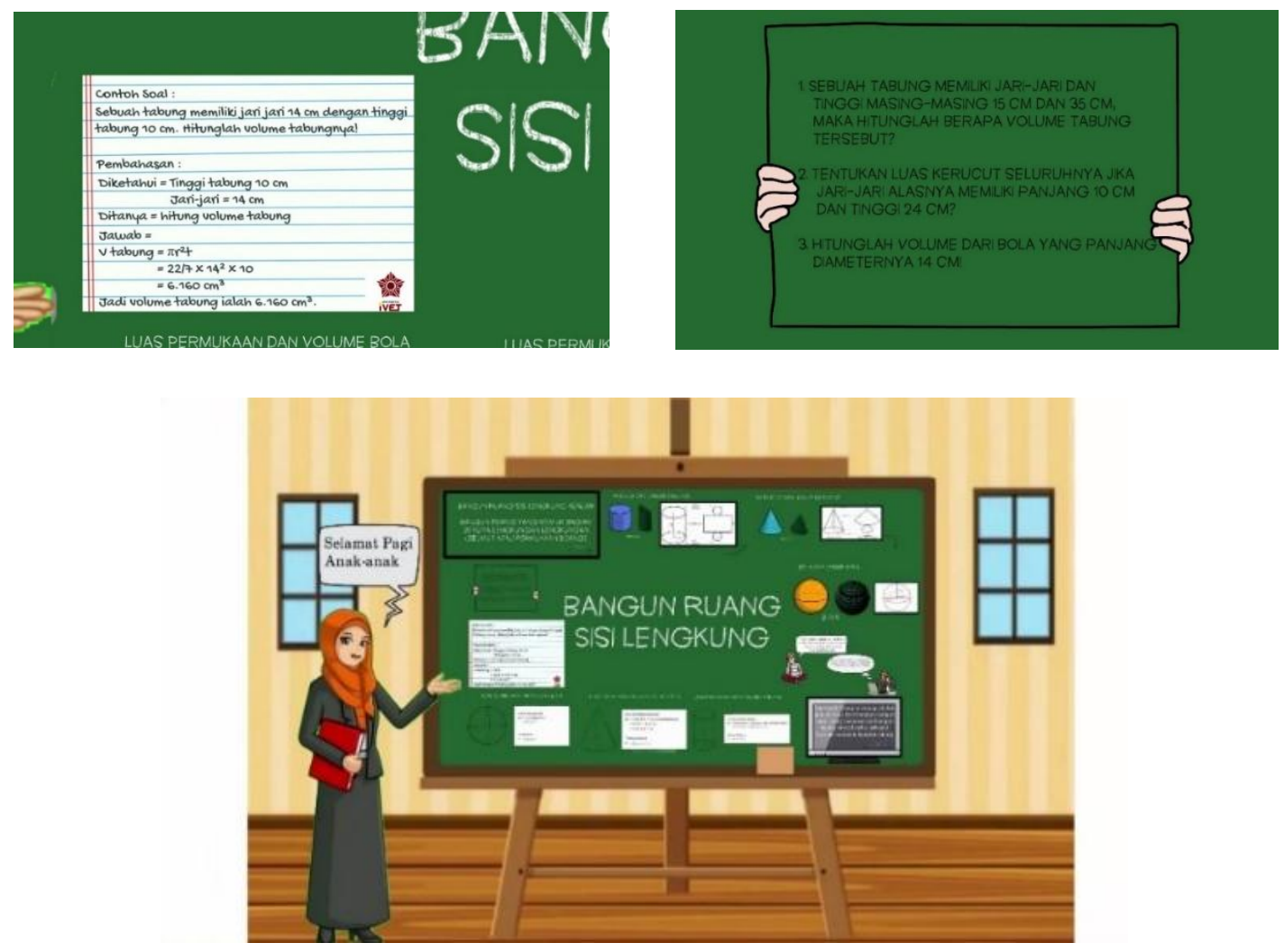

Gambar 12. Contoh Soal dan Akhir Video 

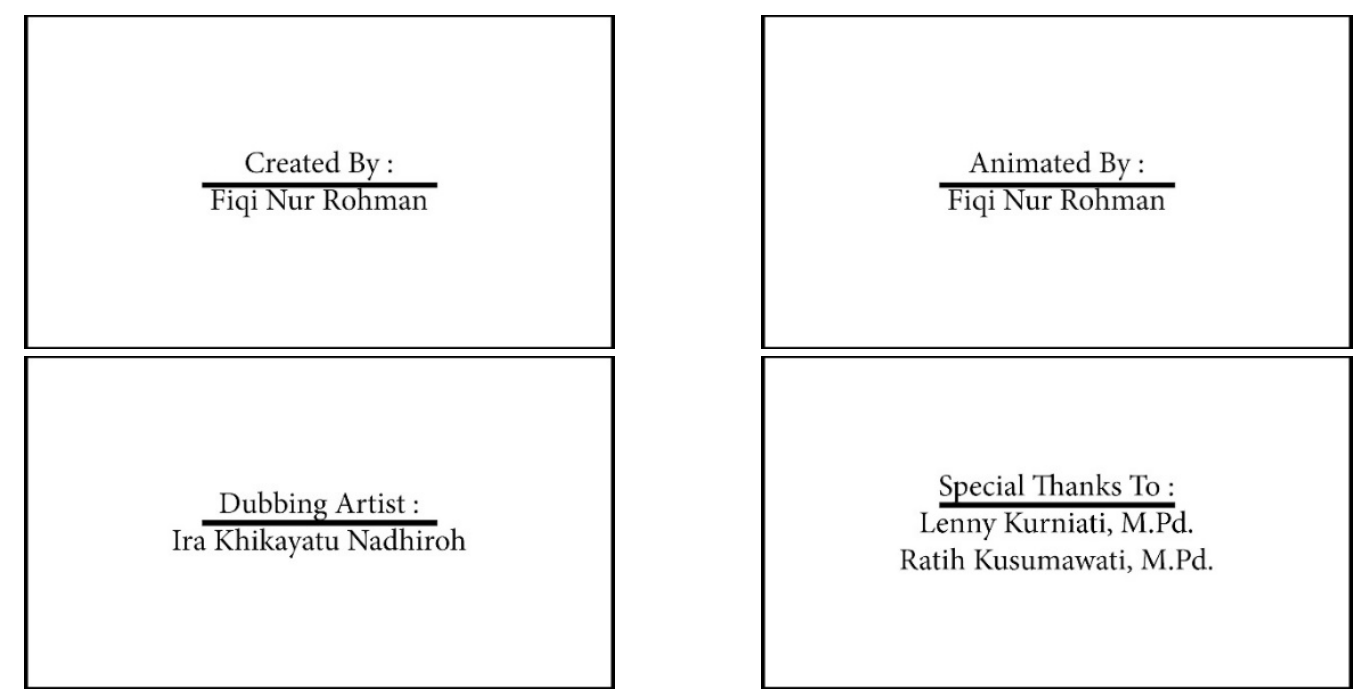

Gambar 13. Credits Video

\section{Pasca Produksi}

Pasca produksi berisi kegiatan editing, yakni kegiatan yang dilakukan untuk menambahkan opening video dan menyelaraskan antara animasi dengan audio narasi. Pada pembuatan video ini program aplikasi yang digunakan adalah Adobe Premiere Pro 2020. Hasil akhir yang dari Video Pembelajaran Matematika ini berupa video dengan format Mp4 dengan durasi 4 menit 29 detik dan Frame Rate 50 Fps. Setelah melalui editing tahap finalisasi produk. Pada tahap ini, video telah memasuki tahap akhir dalam pembuatan video di mana file yang sudah jadi diupload ke Youtube untuk memudahkan akses ke video pembelajaran tersebut.

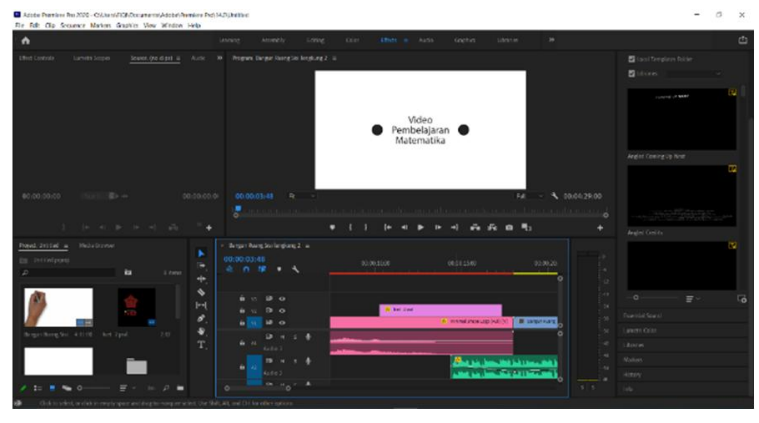

Gambar 14. Proses Editing Video

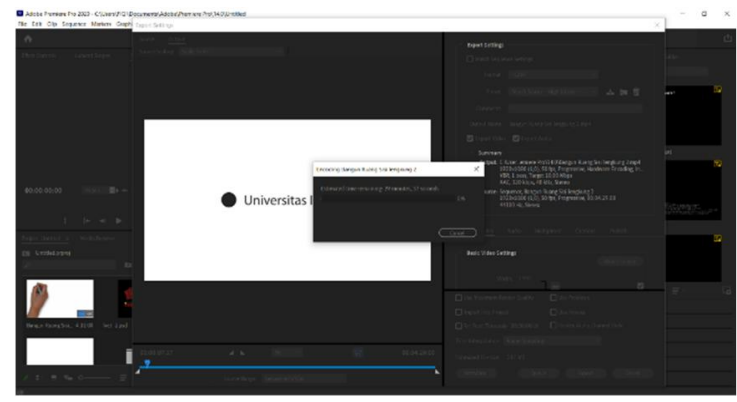

Gambar 15. Proses Rendering Video

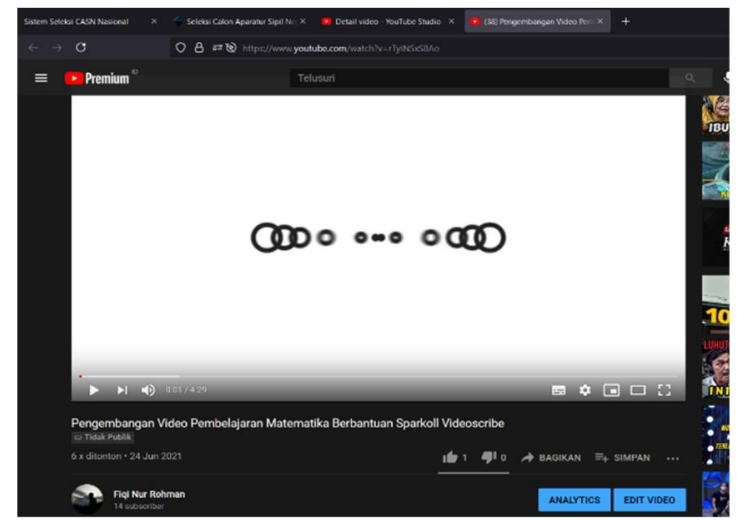

Gambar 16. Video Pembelajaran Yang Sudah Diupload 


\subsection{Preliminary Field Testing}

Media video yang telah selesai dikembangkan sebagai produk awal selanjutnya adalah dilakukan uji coba tahap awal untuk mengetahui kelayakan media sebagai media pembelajaran. Data hasil validasi dan revisi digunakan untuk mengetahui kesesuaian media video dengan kebutuhan berdasarkan pemikiran rasional, dan belum merupakan fakta di lapangan. Uji validitas yang dilakukan dalam penelitian ini meliputi uji validitas dari aspek materi dan uji validitas dari aspek media. Uji validitas dilakukan untuk mengetahui dan mengevaluasi instrumen dan media video yang dikembangkan sesuai dengan tujuan pembelajaran.

Validasi media oleh ahli materi dilakukan untuk menguji validitas/kelayakan media video dilihat dari aspek materi yang meliputi: relevansi materi, kualitas materi, bahasa, dan tipografi yang digunakan pada media video yang sedang dikembangkan. Hasil penilaian dari validasi media Video pembelajaran matematika ini dianalisis menggunakan skala guttman dengan dua alternatif jawaban yaitu "ya" dan "tidak". Skor untuk jawaban ya adalah 1 dan skor untuk jawaban tidak adalah 0. Butir pernyataan terdiri atas 8 butir dengan jumlah ahli adalah 2 orang. Maka diperoleh skor minimum 0 × $8=0$, dan skor maksimum 2 × $8=16$, jumlah kelas adalah 2, panjang intervalnya adalah 8 .

Validasi media oleh ahli media dilakukan untuk menguji validitas/kelayakan media video dilihat dari aspek fungsi dan manfaat media, aspek visual media, aspek audio media, aspek tipografi, bahasa, dan pemrogaman media video sebagai media pembelajaran. Hasil penilaian dari validasi media Video pembelajaran matematika ini dianalisis menggunakan skala guttman dengan dua alternatif jawaban yaitu "ya" dan "tidak". Skor untuk jawaban ya adalah 1 dan skor untuk jawaban tidak adalah 0 . Butir pernyataan terdiri atas 13 butir dengan jumlah ahli adalah 2 orang. Maka diperoleh skor minimum $0 \times 13=0$, dan skor maksimum 2 × $13=26$, jumlah kelas adalah 2, panjang intervalnya adalah 13.

Tabel 3. Hasil Validasi Media oleh Ahli Materi

\begin{tabular}{ccc}
\hline Ahli Materi & Skor & Kelayakan \\
\hline Ahli 1 & 8 & Layak \\
Ahli 2 & 8 & Layak \\
Skor Total & 16 & Layak \\
& Tabel 4. Hasil Validasi Media oleh Ahli Media \\
\hline Ahli Media & Skor & Kelayakan \\
\hline Ahli 1 & 13 & Layak \\
Ahli 2 & 13 & Layak \\
Skor Total & 26 & Layak \\
\hline
\end{tabular}

\subsection{Main Product Revision}

Tahap selanjutnya adalah melakukan revisi media berdasarkan penilaian yang diberikan oleh ahli media dan ahli materi. Tahap ini diperlukan guna meminimalisir kelemahan dan kekurangan dari media itu sendiri. 

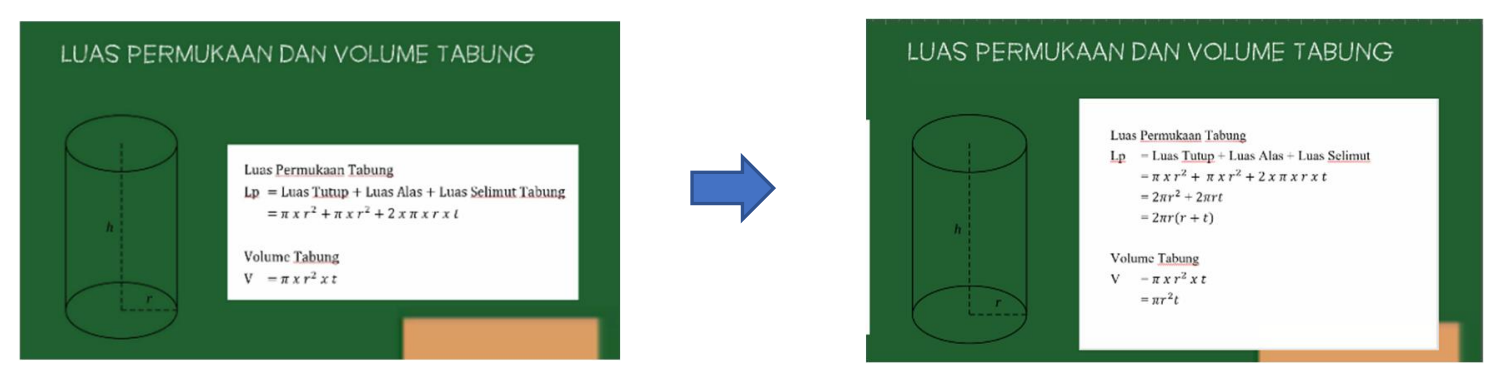

Gambar 17. Revisi Penulisan Rumus Tabung
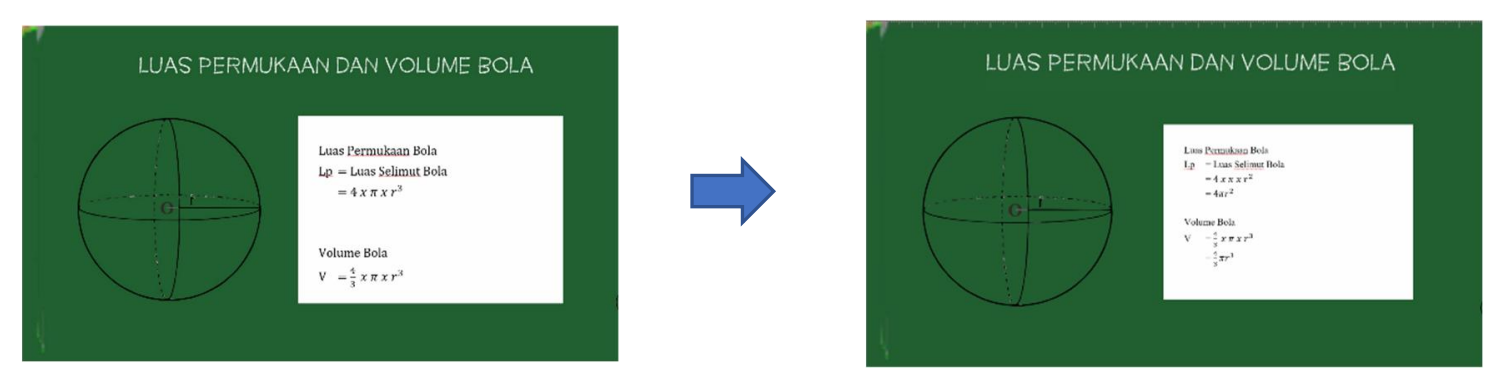

Gambar 18. Revisi Penulisan Rumus Bola

\subsection{Main Field Testing}

Aspek yang dinilai pada uji coba lapangan terdiri atas aspek fungsi dan manfaat, penyajian program, bahasa, dan tipografi. Uji coba lapangan dilakukan kepada 28 siswa di MTs NU 17 Kyai Jogoreso Kendal. Hasil penilaian pada media video tersebut menunjukkan bahwa dari 10 item pernyataan yang dinilai siswa, menyatakan bahwa 116 item dengan skor 4 (Sangat Baik), 141 item dengan skor 3 (Baik) dan 19 item dengan skor 2 (Tidak Baik), dan 4 dengan skor 1 (Sangat Tidak Baik).

Butir yang memiliki skor 1 (Sangat Tidak Baik) adalah butir instrumen nomor 8 yang berisi tentang aspek Audio (Penyajian Program) di dalam media video. Siswa memilih jawaban tidak setuju karena volume audio yang ada dalam video lebih kecil dibandingkan volume dari narator. Meskipun demikian, kelebihan dari video yang dapat menampilkan gambar (visual) dan suara (audio) dapat tetap memudahkan siswa dalam memahami isi materi tanpa harus dapat membaca sehingga butir instrumen tersebut tidak dihilangkan.

Berdasarkan skor data penilaian yang diujikan kepada 28 siswa SMP yang mengisi angket berisi 10 item pernyataan dengan penskoran jawaban sangat baik $=116$ item (skor 4), baik = 141 item (skor 3), tidak baik $=19$ item (skor 2), dan sangat tidak baik $=4$ (skor 1). Grafik respon siswa dapat dilihat pada Gambar 19. 


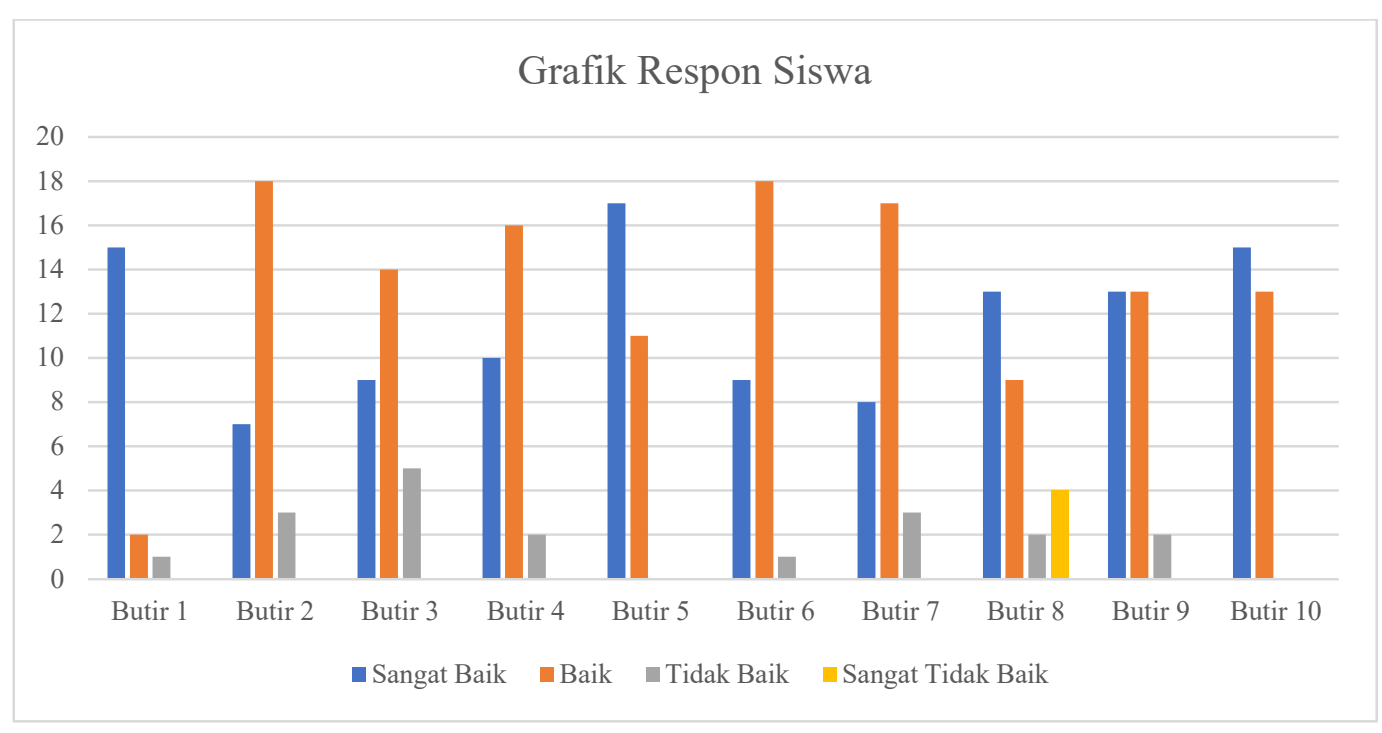

Gambar 19. Grafik Respon Siswa

\subsection{Pembahasan}

Berdasarkan hasil penelitian yang telah dilakukan, peneliti menemukan bahwa penggunaan media pembelajaran di MTs NU 17 Kyai Jogoreso masih jarang digunakan, oleh karena itu peneliti memutuskan untuk mengembangkan media pembelajaran karena media pembelajaran dianggap mampu menyajikan konten pembelajaran yang menarik dan menggugah semangat siswa untuk mengikuti pembelajaran. Hal tersebut sesuai dengan teori yang dikemukakan oleh (Daryanto, 2010) bahwa media pembelajaran merupakan segala sesuatu yang mampu menyampaikan pesan sehingga dapat merangsang perhatian, minat, pikiran dan perasaan siswa dalam kegiatan belajar untuk mencapai tujuan pembelajaran tertentu.

Media yang dipilih dalam pengembangan ini adalah Sparkoll videoscribe karena media tersebut dapat menyajikan konten yang sesuai dengan pembelajaran. Sparkoll videoscribe merupakan media visual yang mampu menyajikan pembelajaran dengan didukung konten gambar, grafis, suara dan animasi yang menarik dan dapat disesuaikan dengan tujuan pembelajaran. Media tersebut juga dapat memberikan kenyamanan bagi siswa dalam menikmati pembelajaran sehingga siswa dapat mengorganisasikan informasi yang terkandung di dalamnya. Hal tersebut selaras dikemukakan Sutikno dan Fathurrohman dalam (Fadillah \& Bilda, 2019) yaitu: Dalam aktivitas pembelajaran, media dapat didefinisikan sebagai sesuatu yang dapat membawa informasi dan pengetahuan dalam Interaksi yang berlangsung antara pendidik dan peserta didik.

Pengembangan media Sparkoll Videoscribe juga melalui validasi media oleh ahli materi dan ahli media. Validasi yang dilakukan ke ahli materi mendapatkan skor 16 dari kedua validator dengan masing-masing memberikan nilai 8 dari 8 . Sedangkan validasi yang dilakukan oleh ahli media memperoleh nilai 26 dari kedua validator dengan masing-masing validator memberikan nilai 13 dari 13. Sehingga dapat disimpulkan bahwa media video mata pelajaran matematika ini sudah memenuhi kelayakan media sebagai media pembelajaran.

Tahap akhir dari pengembangan media Sparkoll Videoscribe adalah uji coba lapangan. Uji coba lapangan dilakukan kepada 28 siswa MTS dengan menggunakan angket respon media. Berdasarkan hasil Uji coba lapangan yang dilakukan kepada 28 Siswa SMP (responden) 
didapatkan skor dengan nilai 3,3179 (dibulatkan menjadi 3,32), apabila dilihat pada tabel di atas, maka nilai tersebut berada pada kategori Sangat Baik antara 3,25 $\leq \mathrm{V} \leq 4,00$, sehingga dapat diinterpretasikan bahwa media Video Pembelajaran Matematika Berbantuan Sparkoll Videoscribe ini telah layak digunakan sebagai media video pembelajaran meskipun dengan perbaikan penyesuaian Audio dalam video tersebut.

Berdasarkan pembahasan hasil pengembangan video pembelajaran matematika berbantuan sparkol videoscribe, dapat disimpulkan bahwa media video mata pelajaran matematika layak digunakan dalam proses pembelajaran serta dapat diproduksi sebagai media pembelajaran bagi siswa SMP. Hal tersebut sesuai dengan teori yang dikemukakan atmojo dalam (Wulandari, 2016) bahwa pengembangan merupakan suatu usaha yang dilakukan secara sadar, terencana, terarah untuk membuat atau memperbaiki sesuatu agar semakin bermanfaat untuk meningkatkan kualitas dan mutu menjadi lebih baik.

\section{SIMPULAN}

Media Video Pembelajaran Matematika Berbantuan Sparkoll Videoscribe dapat dikembangkan melalui penelitian dan pengembangan (Research and Development) dengan menggunakan prosedur menurut Borg and Gall yang disederhanakan menjadi 6 tahap pengembangan, yaitu: (a) penelitian dan pengumpulan informasi, (b) tahap perencanaan yang meliputi pembuatan jadwal penelitian dan menentukan instrumen, (c) tahap pengembangan awal produk meliputi tahap pra produksi (identifikasi program, membuat sinopsis, dan membuat storyboard), tahap produksi (membuat animasi dan rekam suara), tahap pra produksi (editing dan finalisasi), (d) uji coba lapangan awal, (e) revisi media berdasarkan uji coba lapangan awal, (f) uji coba lapangan, menyatakan layak sehingga video dapat digunakan sebagai media pembelajaran untuk siswa SMP/MTS.

Media video pembelajaran matematika yang dikembangkan melalui penelitian dan pengembangan (Research and Development) memiliki tingkat kelayakan yang tergolong dalam kategori layak. Uji coba lapangan awal yang dilakukan pada ahli materi dan ahli media (validator) menunjukkan bahwa skor keseluruhan 16 dari ahli materi dalam interval $8 \leq \mathrm{S} \leq 16$ dan 26 dari ahli media dalam interval $13 \leq \mathrm{S} \leq 26$, sehingga dapat dikatakan media video pembelajaran matematika ini valid digunakan sebagai media pembelajaran. Sedangkan hasil kelayakan media video mata pelajaran matematika pada uji coba lapangan pada 28 orang siswa SMP (responden) menunjukkan bahwa skor akhir responden adalah 3,32 dalam interval 3,25 $\leq$ $\mathrm{S} \leq 4,00$ dalam kategori sangat baik, sehingga dapat dikatakan media video ini tergolong dalam kategori layak. Ini berarti bahwa media video pembelajaran matematika berbantuan Sparkoll Videoscribe valid dan layak digunakan sebagai media pembelajaran bagi siswa SMP/MTS.

\section{DAFTAR PUSTAKA}

Basuki, K. H. (2019). Pengaruh Kecerdasan Spiritual dan Motivasi Belajar terhadap Prestasi Belajar Matematika. Formatif: Jurnal Ilmiah Pendidikan MIPA, 3(2), 79-87.

Borg, W. R., \& Gall, M. . (1983). Educational Research: An Introduction. Longman.

Daryanto. (2010). Media Pembelajaran: peranannya sangat penting dalam mencapai tujuan pembelajaran. Gava Media. 
Eko Putro, W. (2013). Teknik Penyusunan Instrumen Penelitian. Pustaka Pelajar.

Fadillah, A., \& Bilda, W. (2019). Pengembangan Video Pembelajaran Matematika Berbantuan Aplikasi Sparkoll Videoscribe. Jurnal Gantang, 4(2), 177-182.

Herliandy, L. D., Nurhasanah, Suban, M. E., \& Kuswanto, H. (2020). Pembelajaran Pada Masa Pandemi Covid-19. Jurnal Tennologi Pendidikan, 22(1), 65-70.

Indriyani, \& Ganda Putra, F. (2018). Media Pembelajaran Berbantuan Sparkol materi Program Linier Metode Simpleks. Desimal : Jurnal Matematika, 1(3), 353-362.

Kustandi, C. (2013). Media Pembelajaran Manual dan Digital. PT Raja Grafindo Persada.

Muhidin, S., \& Abdurrahman, M. (2011). Panduan Praktis Memahami Penelitian. CV. Pustaka Setia.

Musyadat, I. (2015). PENGEMBANGAN MEDIA PEMBELAJARAN BERBASIS VIDEO SCRIBE UNTUK PENINGKATAN HASIL BELAJAR PADA MATA PELAJARAN SOSIOLOGI KELAS X MAN BANGIL.

Nicola, M., Alsafi, Z., Sohrabi, C., Kerwan, A., Al-Jabir, A., Losifidis, C., Agha, M., \& Agha, R. (2020). The socio-economic implications of the coronavirus pandemic (COVID-19): A review. International Journal Of Surgery, 78, 185-193.

Nurfitriyani, M. (2016). MODEL PEMBELAJARAN PROJECT BASED LEARNING TERHADAP KEMAMPUAN PEMECAHAN MASALAH MATEMATIKA. Jurnal Formatif, 6(2), 149-160.

Purnama, P., Erlidawati, \& Nazar, M. (2016). Pengembangan Media Video Animasi Berbasis Videoscribe Pada Materi Koloid Untuk Mahasiswa Program studi Pendidikan Fisika Tahun Akademik 2016/2017. Jurnal Ilmiah Mahasiswa Pendidikan Kimia, 2(3), 253260.

Purwanto, A., Masduki, A., Fahlevi, M., Mufid, A., Agistiawati, E., Cahyono, Y., \& Suryani, P. (2020). Impact ofWork From Home(WFH) on Indonesian Teachers Performance During the Covid-19 Pandemic: An Exploratory Study. International Journal of Advanced Sience and Technology, 29(5), 6235-6244.

Ramadhaniati, R. T., Sunismi, \& El Walida, S. (2021). PEMBELAJARAN VIDEO PEMBELAJARAN BERBASIS SPARKOL (VIDEOSCRIBE) MARETI LIMIT FUNGSI UNTUK SISWA SMA KELAS XI. JP3, 16(1), 153-161.

Rosiyanti, H., Eminita, V., \& Riski. (2020). DESAIN MEDIA PEMBELAJARAN GEOMETRI RUANG BERBASIS POWTOON. FIBONACCI, 6(1), 77-86.

Sadiman. (2014). Media Pendidikan: Pengertian, Pengembangan dan Manfaatnya. PT Raja Grafindo Persada.

Sugiyono, P. D. (2013). Metode Penelitian Kuantitatif Kualitatif dan R\&D. ALFABETA, CV.

Wahyuni, N., \& Sulistiyo, E. (2017). PENGEMBANGAN MEDIA PEMBELAJARAN COMPACT DISC INTERACTIVE (CD-i) BERBASIS VIDEO SCRIBE MENGGUNAKAN MODEL PEMBELAJARAN ADVANCE ORGANIZER PADA MATA PELAJARAN TKB KELAS X TAV DI SMK NEGERI 3 SURABAYA. Jurnal Pendidikan Elektro, 6(2), 161-166.

Wulandari, D. A. (2016). PENGEMBANGAN MEDIA PEMBELAJARAN MENGGUNAKANSPARKOL VIDEOSCRIBEDALAM MENINGKATKAN MINAT BELAJAR SISWA PADA MATA PELAJARAN IPA MATERI CAHAYA KELAS VIII DI SMP NEGERI 01 KERJO TAHUN AJARAN 2015/2016. Universitass Negeri Semarang. 